\title{
Information Literacy Training on the Preparedness of Garut people in Facing Landslide Threats
}

\author{
Eldi Mulyana ${ }^{1}$, Ade Suherman ${ }^{2}$, Triani Widyanti ${ }^{3}$, Tetep ${ }^{4}$, Asep Supriyatna ${ }^{5}$, Fadlika Sulaeman $^{6}$, \\ Hilmi $^{7}$, Nurdin Miptahul Ulum ${ }^{8}$, Irwan Nurkholis ${ }^{9}$, Nia Kurniawan ${ }^{10}$ \\ Program Studi Pendidikan IPS Fakultas PISBS IPI Garut \\ *Email: eldimulyana@institutpendidikan.ac.id
}

\begin{abstract}
The purpose of this study was to analyze the impact of information literacy on the preparedness of the people of Garut Regency in facing the threat of landslide. The data ini this study are the people of Garut Regency who have been affected by landslides based on the 2010 population census based on gender. The research method uses quantitative patterns in the form of surveys. The results showed that the magnitude of the impact of the ability to identify and find the location of information on public awareness in facing the threat of landslides by $38 \%$. The impact of landslide information literacy can increase the preparedness of the people of Garut Regency by $57 \%$. The conclusion is the impact of information literacy has a significant impact on the preparedness of the people of Garut Regency in facing the threat of landslides.
\end{abstract}

Keywords: Information Literacy, Social Awareness, Landslide

\section{Abstrak}

Tujuan penelitian ini adalah untuk menganalisis dampak literasi informasi terhadap kesiapsiagaan masyarakat Kabupaten Garut dalam menghadapi ancaman bencana longsor.Data dalam penelitian ini adalah masyarakat Kabupaten Garut yang selama ini wilayahnya terkena dampak bencana longsor berdasarkan sensus penduduk tahun 2010 dilihat dari jenis kelamin. Metode penelitian menggunakan pola kuantitatif dalam bentuk survey. Hasil penelitian menunjukkan bahwa besarnya dampak dari kemampuan mengidentifikasi dan menemukan lokasi informasi terhadap kepedulian masyarakat dalam menghadapi ancaman bencana longsor sebesar 38\%. Dampak literasi informasi bencana longsor dapat meningkatkan kesiapsiagaan masyarakat Kabupaten Garut sebesar 57\%. Kesimpulannya adalah dampak literasi informasi memiliki dampak yang signifikan terhadap kesiapsiagaan masyarakat Kabupaten Garut dalam menghadapi ancaman bencana longsor.

Kata Kunci: Literasi Informasi, Kesiapsiagaan Masyarakat, Bencana Longsor

\section{Article Info:}

Received 09 April 2020

Accepted 15 April 2020

Available online 31 Agustus 2020

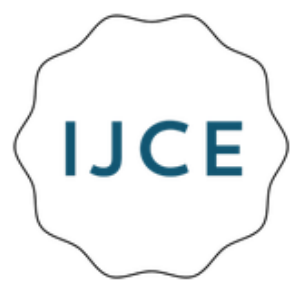




\section{PENDAHULUAN}

Kabupaten Garut berada pada ketinggian 717 mdpl yang dikelilingi oleh empat gunung, yaitu Gunung Cikuray (2821 mdpl), Gunung Papandayan (2622 mdpl), Gunung Karacak (1838 mdpl) dan Gunung Guntur (2249 mdpl). Karakteristik topografi sebelah utara Kabupaten Garut terdiri dari dataran tinggi dan pegunungan, sedangkan bagian selatan memiliki tingkat kecuraman yang terjal. Beberapa kawasan gunung memiliki destinasi wisata yang menguntungkan bagi masyarakat. Ramdhani, dkk. (2016, hlm. 76) mengemukakan bahwa sebagian potensi pariwisata Garut berada pada sektor wisata alam, mulai dari wisata alam pegunungan, wisata pantai, serta wisata buatan. Kabupaten Garut merupakan daerah yang dikelilingi oleh gunung, baik gunung aktif maupun gunung tidak aktif dan semua memiliki ciri khas keunikan tersendiri. Muncul destinasi wisata juga membawa dampak terhadap hadirnya pemukiman yang semakin padat ke arah perbukitan. Berdasarkan topografi Garut, maka beberapa area pemukiman memiliki kerentanan terhadap ancaman bencana longsor. Kabupaten Garut memiliki 42 kecamatan dan sebanyak 11 kecamatan memiliki potensi bencana tanah longsor. Beberapa kejadian bencana longsor sering terjadi di Kabupaten Garut. Masyarakat belum begitu memahami akan ancaman bencana longsor. Fadhli (2019:55) mengemukakan bahwa tanah longsor sering disebut sebagai gerakan tanah, tanah longsor merupakan salah satu bencana yang seringkali terjadi di Indonesia, tanah longsor sering terjadi ketika tibanya musim penghujan, di mana sebagian besar wilayah Ind onesia sering dilanda hujan.

Masyarakat Kabupaten Garut mulai merambah area perbukitan untuk dijadikan pemukiman, perkebunan, peternakan atau bahkan berbisnis tempat penginapan dengan menawarkan view area tersebut. Hal tersebut tentunya akan menimbulkan kerentanan berupa ancaman bencana longsor. Nurjanah, dkk. (2013, hlm. 18) mengemukakan bahwa banyak penduduk memilih atau dengan sengaja tinggal di kawasan yang rawan terhadap bencana dengan berbagai alasan seperti kesuburan tanah, tidak adanya kemampuan ekonomi untuk memiliki rumah dan lain-lain. Besarnya ancaman bencana longsor di Kabupaten Garut sangat membahayakan masyarakat. Tentu harus semakin diperhatikan risiko kerawanan bencana longsor yang dapat menimbulkan korban jiwa. Tanah longsor merupakan ancaman besar setiap tahunnya terhadap hunian-hunian manusia dan infrastruktur. Arifianti (2011, hl. 17) mengemukakan bahwa dalam jangka waktu lama, bencana tanah longsor menyebabkan lebih banyak kerugian dibandingkan bencana lain. Karena itu, ancaman bencana tanah longsor tidak bisa diabaikan oleh masyarakat.

Literasi informasi bencana longsor harus disebarluaskan kepada masyarakat. Literasi informasi bencana longsor yang disampaikan kepada masyarakat harus disesuaikan dengan gaya komunikasi, gaya berpikir dan gaya perilakunya. Sering kita temui secara kontekstual bahwa masyarakat sangat senang dengan smartphone yang mereka miliki dan hampir tiap menit selalu menggunakannya. Karena mereka lahir di era kemajuan teknologi, maka perilaku masyarakat sangat tergantung terhadap teknologi. Mereka bergantung pada internet setiap harinya untuk mencari beragam informasi. Putra (2018, hlm. 67) mengemukakan bahwa ilmu pengetahuan yang terus berkembang dari masa ke masa memengaruhi berbagai aspek yang ada di dunia. Salah satunya perkembangan teknologi digital dan virtual yang terus berkembang sejalan dengan berkembangnya ilmu pengetahuan. Kelancaran dan kenyamanan masyarakat dengan teknologi informasi membuat mereka memiliki perspektif yang positif tentang teknologi yang dapat memengaruhi mereka.

Pentingnya peran pemerintah Kabupaten Garut dan Badan Penanggulangan Bencana Daerah (BPBD) dalam memfasilitasi peningkatan literasi informasi bencana longsor kepada masyarakat. Ketika penulis melihat website institusi pemerintah tersebut ternyata masih belum memadai dalam menjelaskan konten berbentuk poster digital yang dapat dimanfaatkan oleh masyarakat dalam memahami bahaya bencana longsor (Mulyana, dkk, 2019, hlm. 236). Tentunya di era Revolusi Industri 4.0 yang serba digital dan big data harus dimulai oleh stakeholder dalam memberikan wawasan kepada masyarakat untuk memiliki sikap peduli terhadap bahaya dan ancaman longsor di areanya. Adat istiadat masih kental memengaruhi perspektif masyarakat di Kabupaten Garut. Tak terkecuali pada saat mereka dihadapkan dengan bencana longsor. Hal tersebut dipegang teguh oleh masyarakat sekitar dan mereka tidak berani merubah paradigma yang ada karena dikhawatirkan terjadi sesuatu pada diri dan keluarganya. Mitologi pun masih berkembang di kalangan masyarakat dan hal tersebut tercermin dalam obrolan mereka ketika menyangkut bencana alam. Siloka (simbol) alam yang terjadi mereka percayai sebagai kemarahan 
leluhurnya akibat tindakan yang tidak senonoh dan dianggap merusak lingkungan sehingga terjadilah bencana khususnya longsor. Ningrum (dalam Dewi dan Istiadi, 2016, hlm. 133) mengemukakan bahwa pada masyarakat tradisional, dinamika masyarakat terproteksi oleh adat istiadat, dalam hal ini tradisi merupakan tali pengikat yang kuat dalam membangun tata tertib masyarakat. Pelestarian adat istiadat dan kearfan tradisional yang mampu memitigasi bencana dilakukan masyarakat melalui proses belajar tentang nilai-nilai hidup selaras dengan alam, dari sejak dini dalam lingkungan keluarga melalui keteladanan orang tua, pembiasaan dan ajakan.

Kesiapsiagaan masyarakat Kabupaten Garut terhadap ancaman bencana longsor sangat diperlukan. Hal tersebut untuk meminimalisir dampak yang ditimbulkan dari bencana tersebut. Namun, bilamana edukasi berupa mitigasi bencana tidak dipahami dengan baik oleh masyarakat, maka akan menimbulkan masalah dikemudian hari. Ulum (2014, hlm. 23) mengemukakan bahwa kerentanan manusia mencerminkan kurangnya kapasitas masyarakat untuk mengantisipasi, mengatasi, dan memulihkan dari dampak bahaya. Salah satu penyebab kurangnya kapasitas ini tidak lain karena masyarakat sendiri tidak memahami karakteristik dari ancaman bencana. Sehingga saat bencana terjadi secara tiba-tiba, masyarakat tidak siap menghadapinya. Karena itu, peneliti sangat antusias melakukan penelitian terhadap literasi informasi bencana longsor kepada masyarakat Kabupaten Garut dengan tujuan untuk meningkatkan kesiapsiagaan masyarakat dalam menghadapi ancaman bencana longsor.

Berdasarkan latar belakang penelitian berkaitan dengan masalah yang dikemukakan, maka rumusan masalahnya adalah "bagaimana dampak literasi informasi terhadap kesiapsiagaan masyarakat Kabupaten Garut dalam menghadapi ancaman bencana longsor?". Berikut rincian pertanyaan yang diajukan peneliti:

1. Bagaimana dampak kemampuan mengidentifikasi dan menemukan lokasi informasi terhadap kesiapsiagaan masyarakat dalam menghadapi ancaman bencana longsor?

2. Bagaimana dampak kemampuan mengevaluasi informasi secara kritis terhadap kesiapsiagaan masyarakat dalam menghadapi bencana longsor?

3. Bagaimana dampak kemampuan mengorganisasi dan mengintegrasikan informasi ke dalam pengetahuan yang sudah ada terhadap kesiapsiagaan masyarakat dalam menghadapi ancaman bencana longsor?

4. Bagaimana dampak kemampuan memanfaatkan serta mengkomunikasikan informasi secara efektif, legal, dan etis terhadap kesiapsiagaan masyarakat dalam menghadapi ancaman bencana longsor?

5. Bagaimana kesiapsiagaan masyarakat Kabupaten Garut dalam menghadapi ancaman bencana longsor?

Berdasarkan rumusan masalah penelitian yang telah dibuat, maka peneliti mengarahkannya kepada tujuan penelitian. Adapun tujuan penelitannya, yaitu:

1. Menganalisis dampak kemampuan mengidentifikasi dan menemukan lokasi informasi terhadap kesiapsiagaan masyarakat dalam menghadapi ancaman bencana longsor.

2. Menganalisis dampak kemampuan mengevaluasi informasi secara kritis terhadap kesiapsiagaan masyarakat dalam menghadapi bencana longsor.

3. Menganalisis dampak kemampuan mengorganisasi dan mengintegrasikan informasi ke dalam pengetahuan yang sudah ada terhadap kesiapsiagaan masyarakat dalam menghadapi ancaman bencana longsor.

4. Menganalisis dampak kemampuan memanfaatkan serta mengkomunikasikan informasi secara efektif, legal, dan etis terhadap kesiapsiagaan masyarakat dalam menghadapi ancaman bencana longsor.

5. Menganalisis kesiapsiagaan masyarakat Kabupaten Garut dalam menghadapi ancaman bencana longsor.

\section{METODE}

Populasi dalam penelitian ini adalah dilihat dari dua aspek penelitian, yaitu terhadap wilayah Kabupaten Garut dan masyarakat yang terkena dampak bencana longsor. Bungin (dalam Siregar, 2013, hlm. 30) mengemukakan bahwa dalam metode penelitian kata populasi amat populer dipakai untuk menyebutkan serumpun/sekelompok objek yang menjadi sasaran penelitian. Populasi penelitian 
merupakan keseluruhan (universum) dari objek penelitian yang dapat berupa manusia, hewan, tumbuhtumbuhan, udara, gejala, nilai, peristiwa, sikap hidup dan sebagainya. Sehingga objek-objek ini dapat menjadi sumber data penelitian. Berikut ini persebaran populasi masyarakat Kabupaten Garut yang selama ini wilayahnya terkenda dampak bencana longsor berdasarkan sensus penduduk tahun 2010 dilihat dari jenis kelamin:

Tabel 1. Persebaran Populasi Masyarakat Berdasarkan Jenis Kelamin Di Beberapa Kecamatan Wilayah Kabupaten Garut Yang Memiliki Ancaman Bencana Longsor

\begin{tabular}{|c|l|r|r|r|}
\hline No & \multicolumn{1}{|c|}{ Kecamatan } & Laki-laki & \multicolumn{1}{c|}{ Perempuan } & \multicolumn{1}{c|}{ Total } \\
\hline 1 & Kecamatan Talegong & 15.394 & 15.321 & 30.715 \\
\hline 2 & Kecamatan Cisewu & 16.663 & 16.313 & 32.976 \\
\hline 3 & Kecamatan Caringin & 15.083 & 14.483 & 29.566 \\
\hline 4 & Kecamatan Bungbulang & 30.041 & 29.618 & 59.659 \\
\hline 5 & Kecamatan Pakenjeng & 33.251 & 32.501 & 65.752 \\
\hline 6 & Kecamatan Pamulihan & 8.803 & 8.767 & 17.570 \\
\hline 7 & Kecamatan Cisompet & 25.066 & 24.782 & 49.848 \\
\hline 8 & Kecamatan Singajaya & 22.770 & 22.739 & 45.509 \\
\hline 9 & Kecamatan Banjarwangi & 28.480 & 27.620 & 56.100 \\
\hline 10 & Kecamatan Cilawu & 50.534 & 49.539 & 100.073 \\
\hline 11 & Kecamatan Cibalong & 20.555 & 20.213 & 40.768 \\
\hline & Total & 266.640 & 261.896 & 528.536 \\
\hline
\end{tabular}

Sumber: Badan Pusat Statistik Kabupaten Garut (2010).

Cresswell (2014, hlm. 218) mengemukakan bahwa prosedur sampling satu tahap merupakan prosedur sampling yang di dalamnya peneliti sudah memiliki akses atas nama-nama dalam populasi dan dapat mensampling sejumlah individu (atau elemen-elemen) secara langsung. Sampel penelitian ini adalah wilayah desa di beberapa kecamatan yang berada di Kabupaten Garut. Penentuan sampel diambil dari wilayah Kabupaten Garut yang berpotensi memiliki ancaman bencana longsor. Morrisan (2012, hlm. 117) mengemukakan bahwa sampel nonprobabilitas adalah sampel terpilih atau purposive sample yang mencakup responden, subjek atau elemen yang dipilih karena karakteristik atau kualitas tertentu, dan mengabaikan mereka yang tidak memenuhi kriteria yang ditentukan. Sementara itu, cara perhitungan sampel menggunakan rumus Taro Yamane sebagai berikut:

$$
\mathrm{n}=\frac{\mathrm{N}}{\left(\mathrm{N} \cdot 0,1^{2}\right)+1}
$$

Keterangan:

$\mathrm{n}=$ ukuran sampel

$\mathrm{N}=$ Ukuran Populasi

$\mathrm{d}^{2}=$ Presisi yang ditetapkan

Berdasarkan rumus di atas, maka perhitungan sampel terhadap masyarakat di 11 kecamatan Kabupaten Garut adalah sebagai berikut:

$\mathrm{n}=\frac{528.536}{\left(528.536 \times 0,1^{2}\right)+1}$

$\mathrm{n}=\frac{528.536}{5286,36}$

$\mathrm{n}=99,98108339197482$ (dibulatkan menjadi 100 orang)

Berdasarkan penghitungan menggunakan rumus Taro Yamane, maka sampel penelitian diambil sebanyak 100 orang dari wilayah Kabupaten Garut yang memiliki resiko ancaman bencana longsor. Sampel 100 orang ini dibagi ke dalam 11 kecamatan di Kabupaten Garut yang selama ini memiliki resiko ancaman bencana. Peneliti membaginya dengan menggunakan rumus sebagai berikut:

$\mathrm{n}_{1}=\frac{\mathrm{N}_{1}}{\mathrm{~N}} \times \mathrm{n}$

Keterangan: 
$\mathrm{n}=$ Jumlah sampel seluruhnya

$\mathrm{n}_{1}=$ Jumlah sampel menurut stratum

$\mathrm{N}=$ Jumlah populasi seluruhnya

$\mathrm{N}_{1}=$ Jumlah populasi menurut stratum

Berdasarkan rumus di atas, maka banyaknya sampel 100 orang dengan jumlah populasi sebanyak 528.536 orang dibagi secara proporsional per kecamatan seperti sebagai berikut:

Kecamatan Talegong $=\frac{30.715}{528.536} \times 100=5,811($ dibulatkan menjadi 6$)$

Kecamatan Cisewu $=\frac{32.976}{528.536} \times 100=6,239($ dibulatkan menjadi 6)

Kecamatan Caringin $=\frac{29.566}{528.536} \times 100=5,593($ dibulatkan menjadi 6$)$

Kecamatan Bungbulang $=\frac{59.659}{528.536} \times 100=11,287($ dibulatkan menjadi 11)

Kecamatan Pakenjeng $=\frac{65.752}{528.536} \times 100=12,440($ dibulatkan menjadi 12)

Kecamatan Pamulihan $=\frac{17.570}{528.536} \times 100=3,324($ dibulatkan menjadi 3$)$

Kecamatan Cisompet $=\frac{49.848}{528.536} \times 100=9,431($ dibulatkan menjadi 9)

Kecamatan Singajaya $=\frac{45.509}{528.536} \times 100=8,610($ dibulatkan menjadi 9)

Kecamatan Banjarwangi $=\frac{56.100}{528.536} \times 100=10,614($ dibulatkan menjadi 11)

Kecamatan Cilawu $=\frac{100.073}{528.536} \times 100=18,933($ dibulatkan menjadi 19)

Kecamatan Cibalong $=\frac{40.768}{528.536} \times 100=7,713($ dibulatkan menjadi 8$)$

Berdasarkan hasil penghitungan rumus di atas, maka sampel penelitian pada wilayah Kabupaten Garut yang berpotensi mengalami bencana longsor tersaji dalam tabel sebagai berikut:

Tabel 2. Sampel Penelitian Wilayah Kabupaten Garut yang berpotensi mengalami bencana longsor

\begin{tabular}{|c|l|c|}
\hline No & Nama Kecamatan Wilayah Kabupaten Garut & Jumlah Sampel Penelitian \\
\hline 1 & Kecamatan Talegong & 6 \\
\hline 2 & Kecamatan Cisewu & 6 \\
\hline 3 & Kecamatan Caringin & 6 \\
\hline 4 & Kecamatan Bungbulang & 11 \\
\hline 5 & Kecamatan Pakenjeng & 3 \\
\hline 6 & Kecamatan Pamulihan & 9 \\
\hline 7 & Kecamatan Cisompet & 9 \\
\hline 8 & Kecamatan Singajaya & 11 \\
\hline 9 & Kecamatan Banjarwangi & 19 \\
\hline 10 & Kecamatan Cilawu & 100 \\
\hline 11 & Kecamatan Cibalong & 8 \\
\hline & Total Sampel Penelitian & \\
\hline
\end{tabular}

Sumber: Hasil Penelitian (2019).

Variabel dalam penelitian ini terdiri dari dampak literasi informasi (variabel bebas) dan kepedulian masyarakat Kabupaten Garut dalam menghadapi ancaman bencana longsor (variabel terikat). Secara ringkas dijelaskan pada tabel berikut ini: 
Tabel 3. Variabel Penelitian

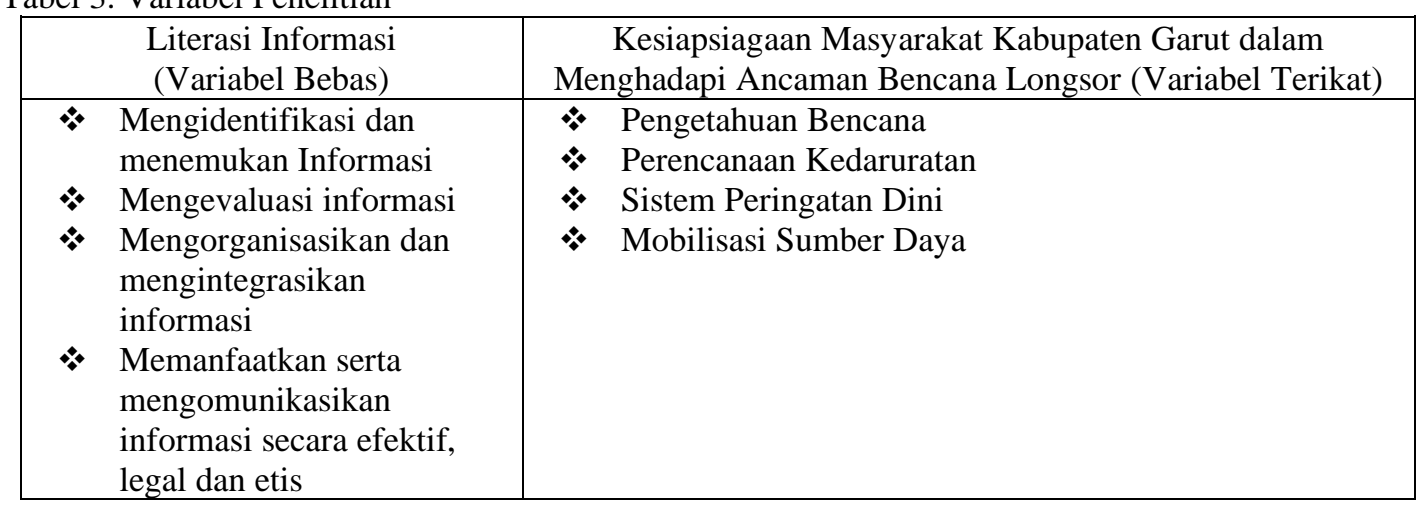

Metode penelitian merupakan cara dari seorang peneliti untuk mendapatkan kesesuaian data untuk menjawab permasalahan yang dirumuskan. Data yang dihasilkan berdasar kepada kontekstual yang terjadi sehingga sangat relevan untuk menjadi ilmu pengetahuan sosial bagi khalayak ramai. Metode penelitian ini menggunakan pendekatan kuantitatif melalui survei kepada masyarakat Kabupaten Garut yang wilayahnya berpotensi mengalami bencana longsor. Zechmester (dalam Emzir, 2013, hlm. 39) mengemukakan bahwa penelitian survei mengilustrasikan prinsip-prinsip penelitian korelasional dan melengkapinya dengan cara yang tepat dan efektif untuk mendeskripsikan pemikiran, pendapat, dan perasaan orang. Berbagai survei berbeda dalam tujuan dan ruang lingkup, tetapi secara umum semuanya melibatkan sampling. Hasil yang diperoleh untuk suatu sampel yang dipilih secara hati-hati dipergunakan untuk mendeskripsikan seluruh populasi objek penelitian yang menarik perhatian kita. Survei juga melibatkan penggunaan suatu set pertanyaan awal yang pada umumnya berbentuk kuesioner.

Teknik pengumpulan data menggunakan observasi lapangan, wawancara, angket, studi literatur, studi dokumentasi. Observasi langsung adalah teknik pengumpulan data dengan melakukan pengamatan secara sistematis terhadap fenomena. Wawancara merupakan metode pengumpulan data yang dikerjakan secara sistematis berdasarakan tujuan penelitian. Angket merupakan alat untuk menggali informasi yang sesuai dengan penelitian dari objek di lapangan. Sementara itu, studi literatur merupakan teknik pengambilan data dari sumber-sumber relevan seperti penelitian-penelitan terdahulu baik berupa jurnal ilmiah atau yang lainnya untuk mempertegas dan mendukung data yang telah didapatkan dari lapangan.

Teknik pengolahan data dilakukan setelah semua data yang dibutuhkan dalam penelitian terkumpul sesuai dengan apa yang menjadi kajian dalam rumusan masalah dan tujuan. Teknik pengolahan data dalam penelitian ini menggunakan editing data, pengkodean, tabulasi data. Analisis data dilakukan sebagai proses untuk mengolah data yang telah dikumpulkan dan juga untuk mengetahui jawaban dari penelitian. Teknik analisis data dilakukan secara kuantitatif melalui uji validitas dan reliabilitas, uji normalitas dan linearitas, uji korelasi untuk mengetahui dampak antar variabel dengan uji $\mathrm{T}$ untuk mengetahui perbandingan kesiapsiagaan masyarakat di 11 kecamatan yang ada di Kabupaten Garut.

Alur penelitian menggunakan beberapa langkah dari mulai mengemukakan latar belakang, merumuskan masalah yang sesuai dengan judul penelitian, membuat tujuan penelitian supaya lebih terarah. Setelah itu peneliti membuat instrumen penelitian yang sesuai, menguji instrumen dengan uji validitas dan reliabilitas, pengumpulan data di lapangan baik primer maupun sekunder. Kemudian peneliti menganalisis deskriptif kuantitatif melalui uji normalitas dan linearitas serta uji korelasi untuk melihat dampak literasi informasi terhadap kepedulian masyarakat Kabupaten Garut dalam menghadapi ancaman bencana longsor. Hasil penelitian dijadikan rekomendasi kepada pemerintah Kabupaten Garut dan masyarakat sehingga dapat diaplikasikan kepada 11 kecamatan yang selama ini berpotensi mengalami bencana longsor maupun yang sering terjadi.

\section{HASIL DAN PEMBAHASAN}

Hubungan antara kemampuan mengidentifikasi dan menemukan lokasi informasi terhadap kesiapsiagaan masyarakat dalam menghadapi bencana longsor ditunjukkan dengan oleh nilai koefisien korelasi yang memperoleh angka 0,385. Hipotesis penelitian yang mengemukakan bahwa terdapat dampak kemampuan mengidentifikasi dan menemukan lokasi informasi terhadap kepedulian 
masyarakat dalam menghadapi ancaman bencana longsor dapat diterima. Besarnya dampak dari kemampuan mengidentifikasi dan menemukan lokasi informasi terhadap kepedulian masyarakat dalam menghadapi ancaman bencana longsor sebesar 38\%. Sementara itu, hubungan kemampuan mengevaluasi informasi secara kritis terhadap kesiapsiagaan masyarakat dalam menghadapi bencana ditunjukkan dengan nilai koefisien korelasi yang memperoleh angka 0,275. Hipotesis penelitian mengemukakan bahwa terdapat dampak kemampuan mengevaluasi informasi secara kritis terhadap kesiapsiagaan masyarakat dalam menghadapi bencana dapat diterima. Besarnya dampak dari kemampuan informasi secara kritis terhadap kesiapsiagaan masyarakat dalam menghadapi bencana longsor sebesar $27 \%$.

Hasil penelitian lainnya menunjukkan bahwa hubungan antara kemampuan mengorganisasikan dan mengintegrasikan informasi ke dalam pengetahuan yang sudah ada terhadap kesiapsiagaan masyarakat dalam menghadapi ancaman bencana longsor ditunjukkan dengan nilai koefisien korelasi yang memperoleh angka 0,271. Hipotesis penelitian menunjukkan bahwa terdapat dampak positif dari kemampuan mengorganisasi dan mengintegrasikan informasi ke dalam pengetahuan yang sudah ada terhadap kesiapsiagaan masyarakat dalam menghadapi bencana longsor dapat diterima. Besarnya dampak dari kemampuan mengorganisasi dan mengintegrasikan informasi ke dalam pengetahuan yang sudah ada terhadap kesiapsiagaan masyarakat dalam menghadapi bencana longsor sebesar $27 \%$.

Hubungan antara kemampuan memanfaatkan serta mengomunikasikan informasi secara efektif, legal dan etis terhadap kesiapsiagaan masyarakat dalam menghadapi bencana longsor ditunjukkan dengan nilai koefisien korelasi yang memperoleh angka 0,285 . Hipotesis penelitian menunjukkan bahwa terdapat dampak kemampuan memanfaatkan serta mengomunikasikan informasi secara efektif, legal dan etis terhadap kesiapsiagaan masyarakat dalam menghadapi bencana longsor dapat diterima. Besarnya dampak kemampuan memanfaatkan serta mengomunikasikan informasi secara efektif, legal dan etis terhadap kesiapsiagaan masyarakat dalam menghadapi bencana longsor sebesar $28 \%$. Berdasarkan informasi data yang diperoleh dari Badan Penanggulangan Bencana Daerah Kabupaten Garut (BPBD), maka dapat diperoleh informasi data bahwa terdapat 11 kecamatan yang memiliki potensi ancaman bencana longsor. Hal tersebut disebabkan oleh topografi yang memiliki tingkat kemiringan lereng yang tinggi. Kecamatan di Kabupaten Garut yang memiliki potensi ancaman bencana longsor adalah Kecamatan Talegong, Cisewu, Caringin, Bungbulang, Pakenjeng, Pamulihan, Cisompet, Singajaya, Banjarwangi, Cilawu, dan Cibalong.

Kesiapsiagaan masyarakat di 11 kecamatan Kabupaten Garut dalam menghadapi ancaman bencana longsor dapat dikategorikan berdasarkan pengisian angket menggunakan skala lima, yaitu sangat siap, siap, kurang siap, tidak siap, dan sangat tidak siap. Teori Carter (1992), LIPI dan UNESCO (2006) menjadi sumber dalam membuat jumlah butir pertanyaan dalam angket yang menegaskan kesiapsiagaan menghadapi bencana longsor dengan modifikasi soal yang berjumlah 15 butir pertanyaan. Rata-rata Ideal (R2) berupa skor maksimal dibagi dua diambil dari 30:2 $=15$, kemudian baru ditentukan Standar Deviasi Ideal (SDI) dengan membagi rata-rata ideal 15:3=5. Berikut ini klasifikasi perhitungan tersebut:

1. $\mathrm{R} 2+1,5 \mathrm{SD}=22,5-30$ termasuk kategori Sangat Siap

2. $\mathrm{R} 2+0,5 \mathrm{SD}=17,5-22,5$ termasuk kategori Siap

3. $\mathrm{R} 2-0,5 \mathrm{SD}=12,5-17,5$ termasuk kategori Kurang Siap

4. $\mathrm{R} 2-1,5 \mathrm{SD}=7,5-12,5$ termasuk kategori Tidak Siap

5. $0-7,5$ termasuk kategori Sangat Tidak Siap

Berdasarkan kategori di atas, maka hasil tingkat kesiapsiagaan masyarakat Kabupaten Garut yang mana 11 kecamatan menjadi sampel dalam penelitian ini tertera pada tabel berikut ini:

Tabel 4. Hasil Tingkat Kesiapsiagaan Masyarakat Kabupaten Garut Di 11 Kecamatan yang menjadi Sampel Penelitian

\begin{tabular}{|c|l|c|c|}
\hline No & \multicolumn{1}{|c|}{ Nama Kecamatan } & Mean & Kategori \\
\hline 1 & Kecamatan Talegong & 14,85 & Kurang Siap \\
\hline 2 & Kecamatan Cisewu & 12,85 & Kurang Siap \\
\hline 3 & Kecamatan Caringin & 15,75 & Kurang Siap \\
\hline 4 & Kecamatan Bungbulang & 16,55 & Kurang Siap \\
\hline 5 & Kecamatan Pakenjeng & 16,25 & Kurang Siap \\
\hline 6 & Kecamatan Pamulihan & 14,35 & Kurang Siap \\
\hline 7 & Kecamatan Cisompet & 15,35 & Kurang Siap \\
\hline
\end{tabular}




\begin{tabular}{|c|l|c|c|}
\hline 8 & Kecamatan Singajaya & 13,95 & Kurang Siap \\
\hline 9 & Kecamatan Banjarwangi & 15,15 & Kurang Siap \\
\hline 10 & Kecamatan Cilawu & 13,75 & Kurang Siap \\
\hline 11 & Kecamatan Cibalong & 16,25 & Kurang Siap \\
\hline & Rata-rata & 14,94 & Kurang Siap \\
\hline
\end{tabular}

Sumber: Hasil Penelitian (2019)

Hasil tabel di atas menunjukkan bahwa untuk tingkat kesiapsiagaan masyarakat di 11 kecamatan wilayah Kabupaten Garut masih sangat rendah. Hal tersebut terbukti dengan kategori yang termasuk ke dalam kurang siap dalam menghadapi ancaman bencana longsor. Skor rata-rata setiap kecamatan berada di kategori kurang siap antara 12,5 - 17,5 dan skor rata-rata sebesar 14,94. Hal tersebut mempertegas tingkat kesiapsiagaan dalam menghadapi bencana longsor diantara 11 kecamatan di wilayah Kabupaten Garut. Karena itu, dapat dipastikan masih sangat rendahnya literasi pada masyarakat Kabupaten Garut yang wilayahnya rawan terhadap bahaya bencana longsor. Hal tersebut semakin diperparah dengan sikap acuh tak acuh masyarakat yang kurang begitu peduli menjaga lingkungan sekitarnya. Pola penggunaan lahan pun menjadi masalah tersendiri di lingkungan masyarakat di mana mereka kebanyakan menanam jenis tumbuhan akar serabut di lahan dengan kemiringan lereng yang curam. Masyarakat cenderung mengabaikan protokol mitigasi bencan. Berikut ini hasil penelitian dari tingkat kesiapsiagaan 11 kecamatan di Kabupaten Garut dalam menghadapi ancaman bencana longsor:

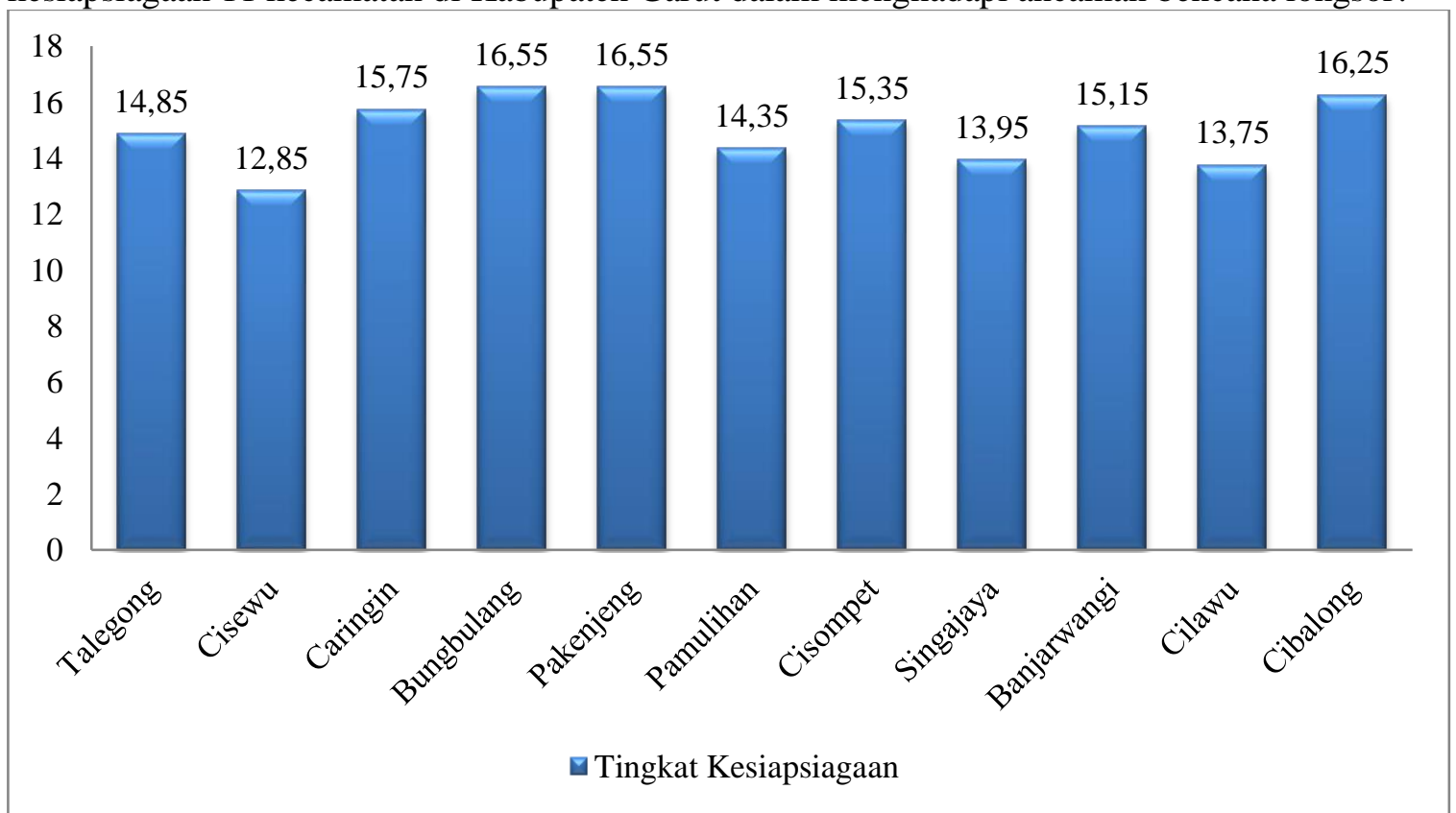

Sumber: Hasil Penelitian, 2019

Gambar 1. Tingkat Kesiapsiagaan 11 Kecamatan di Kabupaten Garut Dalam Menghadapi Ancaman Bencana Longsor

Berdasarkan diagram tersebut dapat dilihat bahwa semua kecamatan di Kabupaten Garut termasuk ke dalam kategori kurang siap dalam menghadapi ancaman bencana longsor. Hal tersebut dikarenakan faktor kekurangtahuan masyarakat akan literasi informasi bencana longsor. Masih banyak masyarakat yang kurang begitu peka terhadap cara mencegah dan menanggulangi bencana longsor di daerahnya. Kebanyakan masyarakat masih memercayai mitologi yang diwariskan turun temurun dari orang tuanya berkaitan dengan mengapa dapat terjadi longsor. Analisa terhadap kesesuaian lahan dan penggunaan lahan belum dipahami betul oleh masyarakat Kabupaten Garut. Rambu-rambu berkaitan dengan mitigasi bencana pun masih sangat kurang belum lagi ditambah medianya yang kurang menarik untuk dibaca bahkan untuk dilihat pun sepertinya masyarakat kurang antusias. Sementara itu, penggunaan lahan yang tidak sesuai tentunya semakin memperparah akan ancaman bencana longsor yang sewaktu-waktu dapat terjadi. Berikut peta titik longsor pada kelas lereng dan peta sebaran titik longsor pada jenis tanah di Kabupaten Garut: 


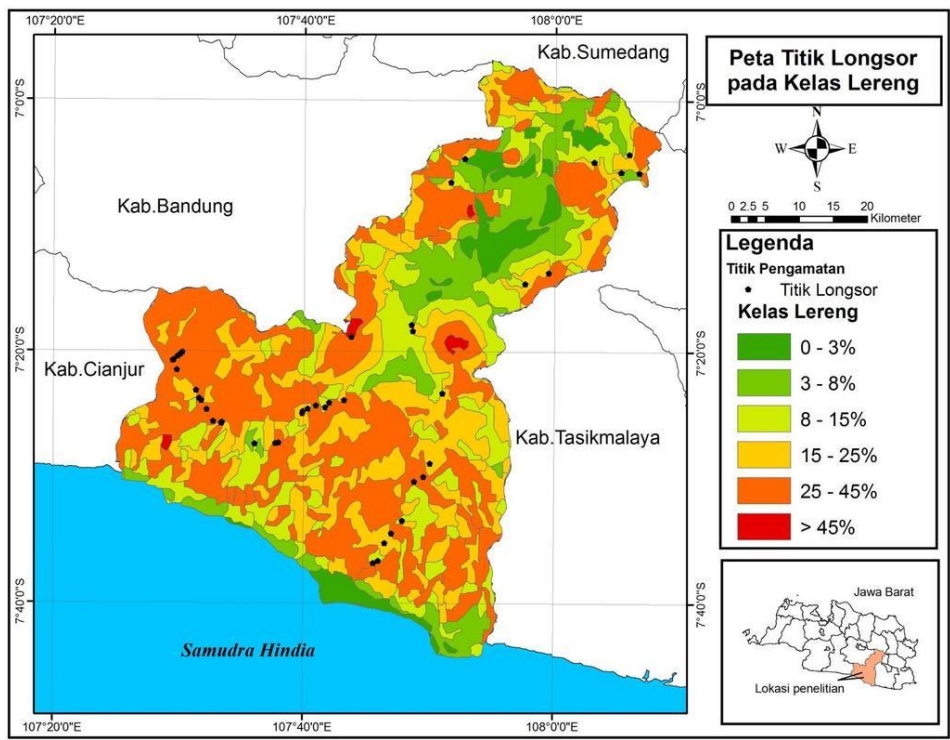

Sumber: BPBD Kabupaten Garut 2019

Gambar 2. Peta Titik Longsor pada Kelas Lereng

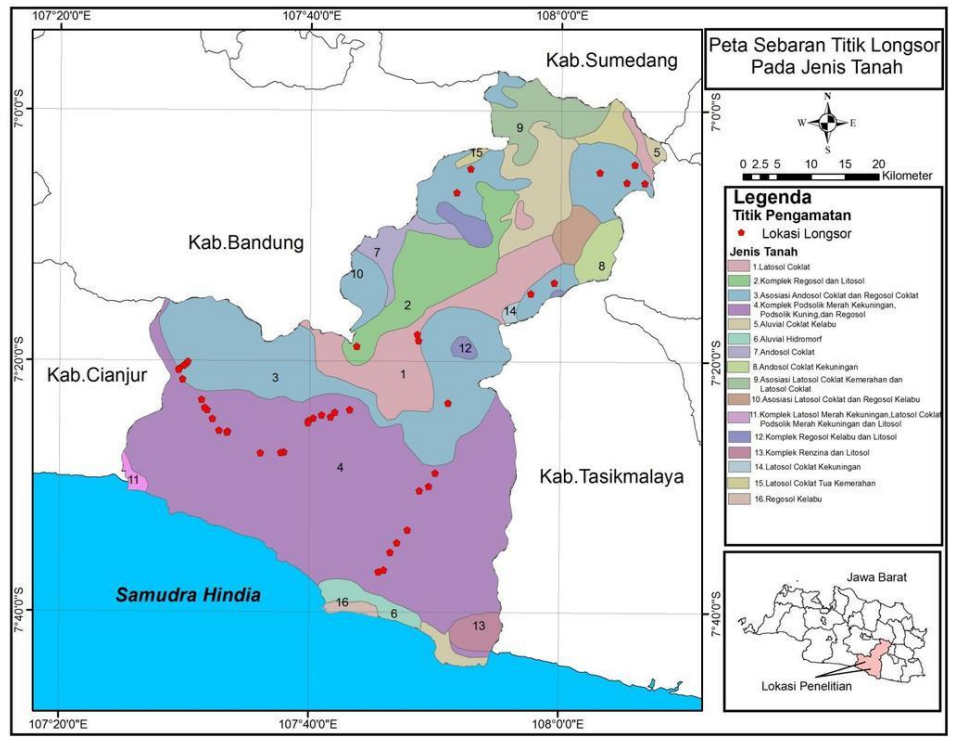

Sumber: BPBD Kabupaten Garut, 2019

Gambar 3. Peta Sebaran Titik Longsor Pada Jenis Tanah

Dampak literasi informasi bencana longsor dapat meningkatkan kesiapsiagaan masyarakat Kabupaten Garut sebesar 57\%. Karena itu, literasi informasi bencana longsor di Kabupaten Garut sangat diperlukan mengingat rawannya beberapa area dan sangat memungkinkan menimbulkan korban jiwa yang lebih banyak. Pihak terkait dalam hal ini pemerintah daerah bekerja sama dengan badan penanggulangan bencana untuk membuat metode literasi informasi kepada masyarakat dengan cara yang mudah dipahami dan dapat diaplikasikan dalam kehidupan sehari-hari. Sebenarnya untuk area tertentu memiliki kearifan lokal dalam mitigasi bencananya. Namun, hal ini banyak dirubah perspektifnya oleh kebutuhan ekonomi masyarakat sekitar yang mengakibatkan anomali pemikiran warisan budaya leluhurnya. Sudah seharusnya pemerintah berperan aktif mengajak masyarakat terutama para pemuda generasi bangsa untuk bersama menciptakan ide kreatif dalam memelihara lingkungan. Konsep edukasi perlu dilakukan dalam pembelajaran di satuan pendidikan terutama dalam mata pelajaran Ilmu Pengetahuan Sosial melalui konsep ekopedagogi pada peserta didik. Hal tersebut sangat penting dilakukan sebagai penanaman konsep pada generasi yang akan datang sebagai bekal literasi informasi terhadap bencana yang sewaktu-waktu bisa terjadi. 


\section{KESIMPULAN DAN SARAN}

Berdasarkan hasil penelitian baik berupa pengolahan data dan analisisnya, maka dapat disimpulkan terdapat dampak yang signifikan dari kemampuan mengidentifikasi dan menemukan lokasi informasi terhadap kesiapsiagaan masyarakat Kabupaten Garut dalam menghadapi ancaman bencana longsor. Kemudian berdasarkan hasil penelitian tersebut bahwa terdapat dampak yang signifikan dari kemampuan mengevaluasi informasi secara kritis terhadap kesiapsiagaan masyarakat Kabupaten Garut dalam menghadapi bencana longsor. Selanjutnya diperoleh informasi terdapat dampak yang signifikan dari kemampuan mengorganisasi dan mengintegrasikan informasi ke dalam pengetahuan yang sudah ada terhadap kesiapsiagaan masyarakat Kabupaten Garut dalam menghadapi ancaman bencana longsor. Selain itu terdapat dampak kemampuan memanfaatkan serta mengkomunikasikan informasi secara efektif, legal, dan etis terhadap kesiapsiagaan masyarakat Kabupaten Garut dalam menghadapi ancaman bencana longsor. Kesimpulan terakhir dalam penelitian kali ini bahwa terdapat perbedaan yang signifikan dari kesiapsiagaan masyarakat Kabupaten Garut dalam menghadapi ancaman bencana longsor. Karena itu, dampak literasi informasi bencana melalui kelengkapan sarana prasarana kebencanaan seperti poster, spanduk, baliho sangat signifikan dan menunjang terhadap kesiapsiagaan masyarakat Kabupaten Garut. Sementara itu, berdasarkan hasil penelitian penting sekali literasi informasi bencana tidak hanya terhadap fenomena longsor saja. Literasi informasi bencana harus dikembangkan lebih luas lagi dengan memanfaatkan teknologi kontemporer dan melibatkan media sosial yang selama ini digandrungi oleh masyarakat seperti facebook, instagram, dan youtube. Bahkan harus semakin diperbanyak literasi informasi tidak hanya bencana alam tetapi bisa mengarah kepada bencana sosial maupun teknologi. Semoga peneliti selanjutnya dapat mewujudkan saran yang bermanfaat bagi khalayak ramai.

\section{REFERENSI}

[1] Arifianti, Y. (2011). Buku Mengenal Tanah Longsor Sebagai Media Pembelajaran Bencana Sejak Dini. Jurnal Bulletin Vulkanologi dan Bencana Geologi. Vol. 6, No. 3, Hal. 17-24.

[2] Cresswell, J.W. (2014). Research Design. Yogyakarta: Pustaka Pelajar.

[3] Dewi, I.K. \& Istiadi, Y. (2016). Mitigasi Bencana Pada Masyarakat Tradisional Dalam Menghadapi Perubahan Iklim Di Kampung Naga Kecamatan Salawu Kabupaten Tasikmalaya. Jurnal Manusia dan Lingkungan, Vol. 23, No. 1, Hal. 129-135.

[4] Emzir. (2013). Metodologi Penelitian Pendidikan Kuantitatif \& Kualitatif. Jakarta: Rajagrafindo Persada.

[3] Fadhli, A., (2019). Mitigasi Bencana. Yogyakarta: Gava Media.

[4] Morrisan. (2012). Metode Penelitian Survei. Jakarta: Prenada Media Group.

[6] Mulyana, E. (2019). Upaya Pemberdayaan Ekonomi, Sosial dan Budaya pada Masyarakat Melalui Pengembangan Bisnis Ekowisata. Business Innovation and Entrepreneurship Journal 1 (1), Hal. 38-43.

[5] Mulyana, E., Nurjaman, N., \& Hilmi (2019). Dampak Literasi Informasi terhadap Kepedulian Masyarakat Kabupaten Garut dalam Menghadapi Ancaman Bencana Longsor. Prosiding Seminar Nasional Pendidikan Geografi Sekolah Pascasarjana Universitas Pendidikan Indonesia, Kontribusi Pendidikan Geografi di Era Revolusi 4.0 2019, Hal. 235-245.

[6] Mulyana, E., Tetep, Widyanti, T. (2019). Analisis Faktor Pendidikan dan Demografi terhadap Tingkat Literasi Ekonomi Mahasiswa. Business Innovation and Entrepreneurship Journal 1 (3), hal. 203-209.

[7] Nurjanah, dkk. (2013). Manajemen Bencana. Bandung: Alfabeta.

[8] Putra, R.A. (2018). Peran Teknologi Digital Dalam Perkembangan Dunia Perancangan Arsitektur. Journal of Islamic Science and Technology, Vol. 4, No. 1, Hal. 67)

[9] Ramdhani, M.F., dkk. (2016). Strategi Pengembangan Desa Mekarjaya Menjadi Desa Wisata Di Kabupaten Garut. Jurnal Manajemen Resort dan Leisure, Vol. 13, No. 2, Hal. 75-85.

[10] Siregar, S.S. (2013). Metode Penelitian Kuantitatif. Jakarta: Kencana Prenada Media Group.

[11] Ulum, C.M. (2014). Manajemen Bencana: Suatu Pengantar Pendekatan Proaktif. Malang: Tim UB Pres. 